\title{
The microbial food web in Arctic seawater: concentration of dissolved free amino acids and bacterial abundance and activity in the Arctic Ocean and in Resolute Passage
}

\author{
Lawrence R. Pomeroy ${ }^{1}$, S. A. Macko ${ }^{2}$, P. H. Ostrom ${ }^{2}$, Janet Dunphy ${ }^{2}$ \\ ${ }^{1}$ Department of Zoology, University of Georgia, Athens, Georgia 30602, USA \\ ${ }^{2}$ Earth Sciences Department, Memorial University of Newfoundland, St. John's, Newfoundland, Canada A1B 3X5
}

\begin{abstract}
In June 1988 the naturally occurring concentration of each of 15 amino acids was less than $20 \mathrm{nM}$ at all depths at a station in the Canadian sector of the Arctic Ocean and at a station in Resolute Passage. In Arctic Ocean water, under the permanent ice pack, bacterial uptake of amino acids and tritiated thymidine was near to below detection, although there were $10^{4}$ to $10^{5}$ heterotrophic bacteria $\mathrm{ml}^{-1}$. In Resolute Passage, uptake of amino acids and thymidine at all depths was low, even at depths where there were visible accumulations of algae which had melted out of the fast ice. Numbers of bacteria were $10^{5} \mathrm{ml}^{-1}$. In water collected in a small, recently opened lead in land-fast ice, containing substantial clumps of ice algae, amino acid concentrations were micromolar and bacterial uptake rates were high. The spring food web of the high Arctic thus appears to be supported mostly by ice algae, and ice algae were sparse under the permanent pack ice at our Arctic Ocean station. Under seasonal ice in Resolute Passage, however, there was copious fallout of ice algae from melting of the bottom of the ice, but the response of the bacteria was limited to lead water having high concentrations of dissolved free amino acids. These observations support previously reported evidence for disparity between algal production and microbial production in polar waters.
\end{abstract}

\section{INTRODUCTION}

Primary and secondary productivity in polar regions are as varied as they are in lower latitudes. Nansen (1902) first reported very low productivity of the region of permanent pack ice of the Arctic Ocean, and this has been confirmed by subsequent studies. English (1959, 1961) reported that photosynthesis was almost totally inhibited in spring by snow-covered ice, and the spring phytoplankton bloom commenced only after snow melt in late June or July. Photosynthetic rates in the region of seasonal ice, from Greenland through the Canadian archipelago, are substantially higher than in the Arctic Basin (Subba Rao \& Platt 1984). Ice algae bloom in spring, and phytoplankton bloom in summer (Welch \& Kalff 1975, Cota et al. 1987). By global acean standards, annual production is moderate in the region of seasonal ice. Yet, in contrast to the region of permanent pack ice, where the higher food chain (fishes, seals, bears) is scant, the productivity of higher organisms in the seasonal ice zone can be substantial. The magnitude and seasonality of primary production must also affect microbial secondary production, but the literature indicates only that microbial production is highly variable in space and time. Therefore, it is of interest to extend our knowledge of microbial processes under the permanent pack ice of the Arctic Ocean and under the seasonal land-fast ice of the Canadian archipelago to establish whether the bacterial heterotrophic processes reflect differences in annual primary production or differences in the ambient concentrations of dissolved organic substrates. During June 1988 we measured dissolved free amino acid concentrations, bacterial numbers, and rates of bacterial uptake of thymidine and amino acids at 2 sites, one in the permanent ice pack and one in the seasonal ice.

\section{STUDY SITES}

In June 1988, the Canadian Ice Island, a free-floating section broken off a tabular glacial ice shelf, was located at $79^{\circ} 37.3^{\prime} \mathrm{N}, 108^{\circ} 51.2^{\prime} \mathrm{W}$, in $480 \mathrm{~m}$ of water, 
near the edge of the continental shelf north of Ellef Ringness Island. This sector of the Arctic Ocean has a mean pack ice cover of $6 \mathrm{~m}$ (Hilber 1980). In June the ice was covered by 1 to $2 \mathrm{dm}$ of snow. Light penetration through that thickness of ice and snow is on the order of $0.01 \%$ of incident radiation (Maykut 1985). There is little empirical information about tides in the Canadian basin, but modeling studies suggest a very small tidal amplitude (Anderson et al. 1988), and we saw no evidence of tidal currents. Resolute Passage and adjacent Barrow Strait, $74^{\circ} 40^{\prime} \mathrm{N}, 95^{\circ} 15^{\prime} \mathrm{W}$, is covered by $2 \mathrm{~m}$ of land-fast ice in June. With a tidal amplitude of about $1 \mathrm{~m}$, ticlal currents under the ice and tidal ice heave near shore are evident.

\section{METHODS}

Water samples were taken through holes cut in firstyear pack ice near the Ice Island and through the landfast ice in Resolute Passage with clean Go-Flo ${ }^{\circledR}$ samplers, using a metered winch. The samplers were emptied immediately and the water was stored in sea ice and seawater at $-1^{\circ} \mathrm{C}$. Experiments were begun within 2 to $4 \mathrm{~h}$ of collection. Ambient salinity, temperature and chlorophyll fluorescence were measured with a Seabird Sea Cat SBE-19 CTD. The fluorometer had been calibrated against HPLC chlorophyll a values $\left(r^{2}=0.99\right.$; A. Reddin pers. comm. $)$. The CTD salinometer was calibrated with water samples measured in an A.G.E. 2100 precision salinometer.

With the exception of ${ }^{14} \mathrm{C}$-bicarbonate uptake, all measurements were time-course studies, in which triplicate samples were filtered for counting every 1 to $2 \mathrm{~d}$ over a 100 to $200 \mathrm{~h}$ period. Controls, which were filtered both at zero time and concurrent with the last sample, showed no significant difference between the initial and final killed controls. Whirl-pak bags in an ice bath were loaded with $10 \mathrm{ml}$ of seawater, labeled compounds were added, and the bags were transferred to styrofoam coolers containing sea ice and seawater for later killing and filtration. Temperature in the coolers was $-1 \pm 0.2^{\circ} \mathrm{C}$. Dry filters in mini-scintillation vials were returned to Athens, GA (USA) for counting. All counts were for $100 \mathrm{~min}$, with both internal and external standardization for quench and counting efficiency

Uptake of tritiated thymidine (New England Nuclear (methyl- ${ }^{3} \mathrm{H}$ ]-thymidine, $3.1 \mathrm{TBq} \mathrm{mmol}^{-1}$ ) was measured by the method of Fuhrman \& Azam (1980), with one additional step: each timed sample was terminated by the addition of $\mathrm{NaOH}$ to kill and disrupt bacterial cells before extraction with TCA (Wicks \& Robarts 1987). Each sample was labeled with $4 \mu \mathrm{Ci}(=5 \mathrm{nM})$. Our limit of significant resolution was about $0.05 \mathrm{pM}$ $\mathrm{d}^{-1}$, although rates as low as $0.002 \mathrm{pM}$ could be detected. We were not able to use the phenolchloroform-ethanol extraction of Wicks \& Robarts (1987) because of problems in transporting and using the required reagents. Comparisons of the 2 methods in Newfoundland at 0 to $-1.8^{\circ} \mathrm{C}$ showed the Wicks \& Robarts method yielding about half the activity of cold $5 \%$ TCA alone. Bailiff et al. (1988), working in Garlache and Bransfield Straits in the Antarctic at water temperatures of 0 to $2^{\circ} \mathrm{C}$, found only 10 to $40 \%$ of thymidine incorporated into DNA. Thus, the method we used, while comparable to most extant literature values, overestimated incorporation of thymidine into DNA (Robarts \& Wicks 1989), and conversion of these values to bacterial secondary production is not straightforward. We did not correct for isotopic dilution. Chrzanowski (1988) found an underestimation of incorporation of tritiated thymidine of 10 to $20 \%$ at low rates of production and low rates of heterotrophic uptake. The underestimation resulting from isotope dilution does not compensate for the overestimation resulting from counting the gross TCA precipitate.

Ambient concentrations of amino acids in seawater were measured with a portable HPLC system within 2 to $4 \mathrm{~h}$ of collection. The $\mathrm{pH}$ of the sample was adjusted to $<5$ with the addition of quartz-distilled $\mathrm{HCl}$. A $100 \mu \mathrm{l}$ portion of this solution was injected into the amino acid analyzer. Separation of the amino acids was by a stepwise isocratic elution, using a cation exchange $3 \mu \mathrm{m}$ resin (St. John Assoc.). Detection was on postcolumn orthophthaldialdehyde derivatives of the amino acids, using fluorescence and integration (HTV detector and HP 3390A integrator). Details of the field HPLC method are in Silfer et al. (in press). Our seawater concentration limit of quantitative detection of individual amino acids was $20 \mathrm{nM}$.

Leucine uptake was measured by the addition of $1 \mathrm{uCi}$ of tritiated leucine (New England Nuclear L-

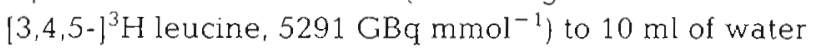
sample in a chilled whirl-pak bag. The amount of added leucine in our tracer studies was 7 pmol, making a final concentration of $0.7 \mathrm{nM}$. Although the ambient concentration was $<20 \mathrm{nM}$, there is likely no significant enrichment by the carrier. The rates we report are assimilation only and do not include leucine that was taken up and respired during the experiment. Kirchman \& Hodson (1984) found $<10 \%$ of assimilated leucine was respired in temperate and tropical waters, but we cannot be certain that this holds for polar waters. Glutamic acid uptake was measured by the addition of $1 \mu \mathrm{Ci}$ of ${ }^{14} \mathrm{C}$-glutamic acid (New England Nuclear L- $\left[{ }^{14} \mathrm{C}(\mathrm{U})\right]$-glutamic acid, $10.8 \mathrm{GBq} \mathrm{mmol}^{-1}$ ) to $10 \mathrm{ml}$ of water sample in a chilled whirl-pak bag. The glutamic acid in our tracer studies brought the concentration to $34 \mathrm{nM}$. In an ambient concentration of $<20 \mathrm{nM}$ this may be an addition of substrate of as 
much as one order of magnitude. The one exception is the experiment with lead water, in which the ambient concentration of glutamic acid was $8 \mu \mathrm{M}$. Respired ${ }^{14} \mathrm{CO}_{2}$ from glutamic acid was trapped in wicks containing phenethylamine, and activity in both wicks and filter residues was counted (Hobbie \& Crawford 1969).

Seawater samples were fixed with acid Lugol's solution at the beginning and end of experiments and were returned to Athens for counting bacteria, evaluating biomass changes, and describing qualitatively the total seston. The samples were stained with acridine orange, filtered onto $0.2 \mu \mathrm{m}$ black Nuclepore ${ }^{(B)}$ filters, and counted with a Zeiss standard epifluorescence microscope at $1200 \times$ magnification (Pomroy 1984, Nishino 1986, Douglas et al. 1987). Biomass was estimated from cell morphology (Lee \& Fuhrman 1987).

To estimate photosynthesis, water taken from depth was placed in $300 \mathrm{ml}$ glass bottles and labeled with $10 \mu \mathrm{Ci}{ }^{14} \mathrm{C}$-bicarbonate (New England Nuclear). We took precautions to avoid contamination of the samples with heavy metals and rubber, but we could not use the clean-room procedures that are advocated for oceanic photosynthesis measurements. The bottles were lowered to the original sample depths through a small hole cut in first-year ice and held there for $24 \mathrm{~h}$ (all in daylight). The bottles were enclosed in black plastic bags in sea ice and seawater while being transported from the pack ice to the laboratory hut for filtration.

\section{RESULTS}

The waters of the continental shelf of the Canadian margin of the Arctic Ocean are strongly stratified, with polar surface water of lower salinity in the top $75 \mathrm{~m}$ and polar underwater below a transition layer (cf. Anderson et al. 1989). Chlorophyll fluorescence was quite low at all depths (Fig. 1). Although ice thickness at our sampling site was $<2 \mathrm{~m}$, it was snow-covered and surrounded by thick ice. There was no significant uptake of ${ }^{14} \mathrm{C}$-bicarbonate at any depth in our string of bottles incubated in situ under the ice in the Arctic Ocean. Bacterial numbers were low, from $5 \times 10^{5} \mathrm{ml}^{-1}$ at $30 \mathrm{~m}$ to $1 \times 10^{4} \mathrm{ml}^{-1}$ at greater depths in the Arctic Ocean (Fig. 2). At $30 \mathrm{~m}$ the dominant biomass was single, freeliving bacteria. A small number of micro-colony clusters of 10 to 20 cells was also present. Except for the micro-colonies, organic aggregates were not seen in the surface water. At $180 \mathrm{~m}$ in the Arctic Ocean there were abundant but sterile organic flocculent aggregates. At that depth we also counted $2.8 \times 10^{4} \mathrm{ml}^{-1}$ autofluorescent organisms, $0.5 \mu \mathrm{m}$ in diameter, having the characteristic morphology and phycoerythrin fluorescence of Synechococcus. In the $300 \mathrm{~m}$ sample there were $>10^{4} \mathrm{ml}^{-1}$ flocculent aggregates containing

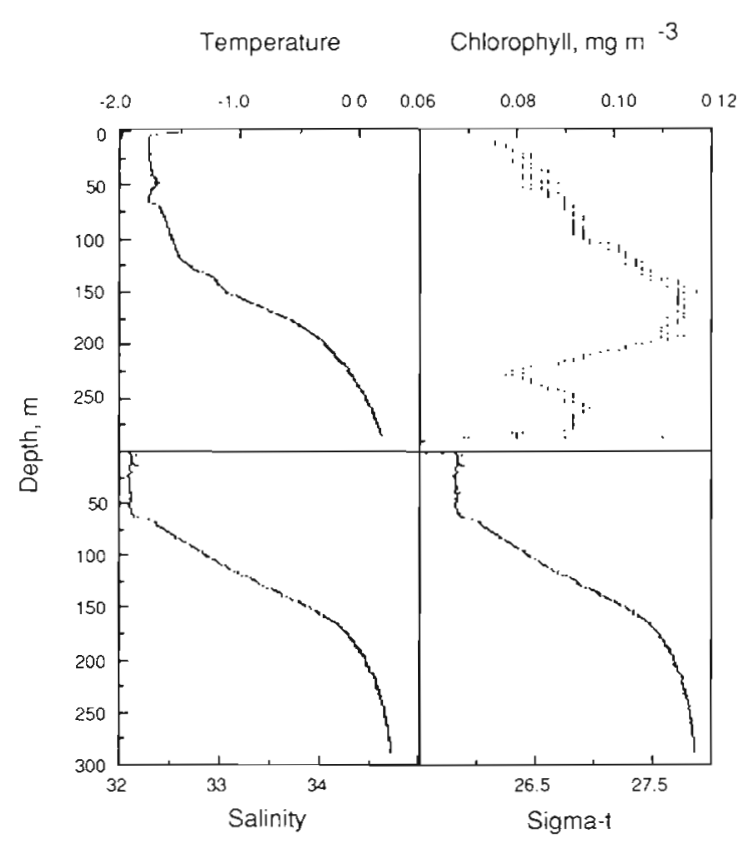

Fig. 1. CTD cast near Canadian Ice Island, 79 37.3' $\mathrm{N}$, $108^{\circ} 51.2^{\prime} \mathrm{W}, 18$ June $1988,17: 30 \mathrm{~h}$, GMT All data points from the downcast are shown

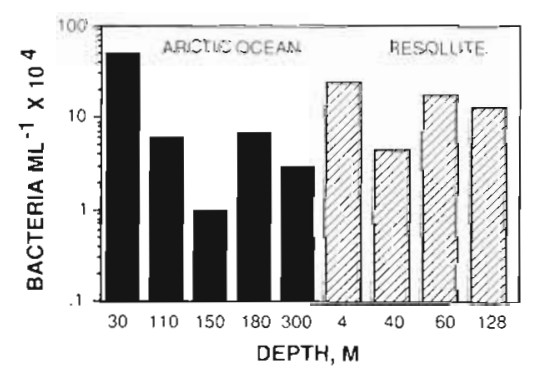

Fig. 2. Abundance of free-living heterotrophic bacteria in the water at the study sites on the Arctic Ocean continental shelf and in Resolute Passage

orange-fluorescing bodies unlike Synechococcus and not having the appearance of viable, intact cells. In the course of counting the bacteria, some flagellated protozoans were observed, but they were not numerous enough to permit an accurate estimate of their abundance with the preserved volume available.

We attempted to collect ice algae under first-year ice near the Ice Island by boring holes and floating up the bottom ice. We also sought ice algae around the edge of a lead. At best, only faint traces of brown color were observed. While we did not verify the presence of ice algae by microscopy, visual inspection suggests that they were present in June although not in bloom concentrations.

Resolute Passage showed little thermohaline stratification (Fig. 3). Numbers of bacteria ranged from $4.5 \times 10^{4}$ to $2.4 \times 10^{5} \mathrm{ml}^{-1}$ (Fig. 2). As in the Arctic 
Ocean their size was 0.1 to $0.3 \mu \mathrm{m}$, and they consisted mostly of cocci with lesser numbers of rods and sigmoid forms. Both numbers and size of bacteria in Resolute Passage were low in comparison with temperate coastal waters. Near the bottom there was an accumulation. of orange-fluorescent detritus, also seen in the fluorometer record (Fig. 3), but no increase in bacterial numbers or biomass. A luxuriant ice algae community was present all over the undersurface of the fast ice in Resolute Passage. The CTD-fluorometer record

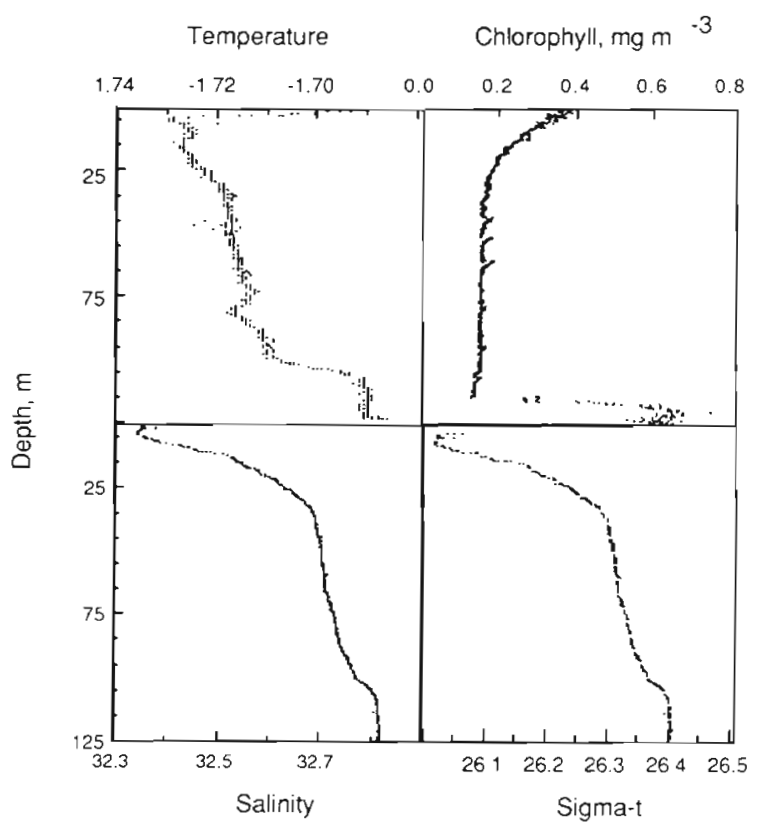

Fig. 3. CTD cast at R. J. Conover's research hut in Resolute Passage, $74^{\circ} 40^{\prime} \mathrm{N}, 95^{\circ} 15^{\prime} \mathrm{W}, 24$ June 1988, 15:30 h, GMT All data points from the downcast are plotted

showed evidence of enhanced chlorophyll directly under the ice, probably from sloughing ice algae, and of a chlorophyll or phaeopigment concentration in the near-bottom nepheloid layer (Fig. 3). Floating clumps of ice algae recently melted out of the bottom of the fast ice did, however, contain dense aggregations of bacteria, mostly 1 to 2 um rods and some 3 to $5 \mu \mathrm{m}$ rods Most bacteria in the clumps were aggregated around detritus and diatom frustules.

Dissolved oxygen values were similar to those previously reported from the Arctic Ocean (Table 1). Most samples in the polar surface water were near saturation, but samples from the underwater showed a quite uniform depletion to ca $70 \%$ saturation.

Concentrations of individual dissolved free amino acids in the open waters, both of the Arctic Ocean and Resolute Passage, were all below our $20 \mathrm{nM}$ limit of quantitative detection. Water from a narrow lead in Resolute Passage in which we collected floating algae
Table 1. Concentration of dissolved oxygen and percent saturation at 1 atm (calculated from the tables of Weiss 1970) taken from Co-Flo samples at the Arctic Ocean station, $79^{\circ}$ $37.3^{\prime} \mathrm{N}, 108^{\circ} 51.2^{\prime} \mathrm{W}$, June 1988

\begin{tabular}{|ccc|}
\hline $\begin{array}{c}\text { Depth } \\
(\mathrm{m})\end{array}$ & $\begin{array}{c}\text { Dissolved } \\
\text { oxygen } \\
\left.(\mathrm{ml})^{-1}\right)\end{array}$ & $\begin{array}{c}\% \\
\text { Saturation }\end{array}$ \\
\hline 10 & 6.94 & 82 \\
20 & 8.37 & 98 \\
30 & 8.19 & 96 \\
40 & 6.97 & 82 \\
50 & 7.68 & 90 \\
140 & 5.81 & 69 \\
150 & 5.95 & 71 \\
180 & 5.60 & 69 \\
200 & 5.47 & 74 \\
280 & 5.95 & 73 \\
300 & 5.81 & \\
\hline
\end{tabular}

that had sloughed out of the ice contained micromolar concentrations, but the total amino acid concentration of this sample was less than that of a sample of adjacent sea ice by a factor of nearly 7 (Table 2). Significant changes in amino acid abundance and proportions of amino acids occurred in this sample, held at $-1.5^{\circ}$ for $48 \mathrm{~h}$, but there was no consistent trend in the data.

At the Arctic Ocean station, uptake of ${ }^{3} \mathrm{H}$-thymidine was measurable in the upper mixed layer but was too low to be quantified in the deeper layers, while in Resolute Passage the uptake was low but measurable at all depths (Table 3). ${ }^{3} \mathrm{H}$-leucine uptake could only be estimated approximately in the lower layers of the Arctic Ocean but was measurable in the upper mixed layer in the Arctic Ocean and at all depths in Resolute Passage (Table 4). An example of the time-course data from each site is presented in Fig. 3. Uptake of ${ }^{14} \mathrm{C}$ glutamic acid also was measurable at all depths at both stations, and assimilation efficiency varied irregularly between 14 and $34 \%$ (Table 5).

\section{DISCUSSION}

Low productivity in the permanent ice pack of the Arctic Ocean has been reported consistently (Apollonio 1959, English 1961), and we were unable to measure phytoplankton production in June. At a location on the Canadian sector of the arctic continental shelf, Appollonio (1959) reported never seeing any amphipods, and he reported sighting only one seal. We saw 1 or 2 amphipods in our sampling hole but saw no evidence of seals. Attempts to catch fish from the Canadian Ice Island have failed, and 2 bears have been seen there in 5 yr. English (1961) reported that photosynthesis began 
Table 2. Dissolved free amino acids in water from a small lead in fast ice of Resolute Passage which contained floating ice algae. Measurements at zero time and after incubation for 12,24 , and $48 \mathrm{~h}$. Final row shows dissolved free amino acids in melted sea ice from Resolute Passage. The upper half of the table shows amino acid concentrations in $\mu \mathrm{M}$. The lower half shows percentages of the total represented by each of the 15 amino acids measured

\begin{tabular}{|c|c|c|c|c|c|c|c|c|c|c|c|c|c|c|c|c|}
\hline $\begin{array}{l}\text { Time } \\
\text { (H) }\end{array}$ & $\begin{array}{c}\text { Aspartic } \\
\text { acid }\end{array}$ & $\begin{array}{l}\text { Threo- } \\
\text { nine }\end{array}$ & Serme & $\begin{array}{l}\text { Gluta- } \\
\text { mic acid }\end{array}$ & Glycine & Alanine & Valıne & $\begin{array}{l}\text { Methio- } \\
\text { nine }\end{array}$ & $\begin{array}{l}\text { Isoleu- } \\
\text { cine }\end{array}$ & $\begin{array}{l}\text { Leu- } \\
\text { cine }\end{array}$ & $\begin{array}{l}\text { Tyro- } \\
\text { sine }\end{array}$ & $\begin{array}{l}\text { Phenyl- } \\
\text { alanine }\end{array}$ & $\begin{array}{l}\text { Histi- } \\
\text { dine }\end{array}$ & $\begin{array}{l}\text { Ly- } \\
\text { sine }\end{array}$ & $\begin{array}{l}\text { Arge- } \\
\text { nine }\end{array}$ & Total \\
\hline \multicolumn{17}{|c|}{$\mu \mathrm{moll}^{-1}$} \\
\hline 0 & 2.87 & 2.53 & 4.30 & 8.06 & 1.71 & 5.65 & 1.36 & 0.76 & 0.91 & 1.72 & 0.59 & 1.30 & 1.60 & 0.75 & 1.35 & 35.44 \\
\hline 12 & 7.96 & 5.98 & 10.69 & 17.40 & 1.76 & 4.78 & 1.04 & 0.59 & 0.67 & 1.20 & 0.32 & 0.37 & 0.84 & 0.87 & 1.22 & 55.68 \\
\hline 24 & 2.48 & 1.86 & 5.13 & 7.62 & 1.85 & 5.71 & 1.26 & 0.71 & 0.87 & 1.70 & 0.95 & 1.28 & 0.93 & 0.81 & 1.26 & 34.41 \\
\hline 48 & 1.64 & 2.71 & 5.32 & 15.60 & 4.47 & 11.71 & 2.58 & 0.98 & 1.85 & 4.33 & 0.71 & 0.85 & 3.88 & 2.85 & 3.87 & 63.35 \\
\hline Ice & 19.53 & 9.94 & 52.10 & 34.03 & 19.42 & 42.40 & 5.35 & 3.37 & 4.36 & 10.79 & 8.06 & 8.71 & 7.28 & 4.48 & 13.45 & 243.26 \\
\hline \multicolumn{17}{|c|}{ Percent } \\
\hline 0 & 8.1 & 7.1 & 12.1 & 22.7 & 4.8 & 15.9 & 3.8 & 2.1 & 2.6 & 4.8 & 1.7 & 3.7 & 4.5 & 2.1 & 3.8 & \\
\hline 12 & 14.3 & 10.7 & 19.2 & 31.3 & 3.2 & 8.6 & 1.9 & 1.1 & 1.2 & 2.2 & 0.6 & 0.7 & 1.5 & 1.6 & 2.2 & \\
\hline 24 & 7.2 & 5.4 & 14.9 & 22.1 & 5.4 & 16.6 & 3.7 & 2.1 & 2.5 & 4.9 & 2.8 & 3.7 & 2.7 & 2.3 & 3.7 & \\
\hline 48 & 2.6 & 4.3 & 8.4 & 24.6 & 7.1 & 18.5 & 4.1 & 1.6 & 2.9 & 6.8 & 1.1 & 1.3 & 6.1 & 4.5 & 6.1 & \\
\hline Ice & 8.0 & 4.1 & 21.4 & 14.0 & 8.0 & 17.4 & 2.2 & 1.4 & 1.8 & 4.4 & 3.3 & 3.6 & 3.0 & 1.8 & 5.5 & \\
\hline
\end{tabular}

Table 3. Uptake of ${ }^{3} \mathrm{H}$-thymidine at 2 locations in the Arctic

\begin{tabular}{|lrcc|}
\hline Location & $\begin{array}{c}\text { Depth } \\
(\mathrm{m})\end{array}$ & $\begin{array}{c}\mathrm{pmol} \\
\mathrm{h}^{-1}\end{array}$ & $\mathrm{r}^{2}$ \\
\hline Arctic Ocean, $79^{\circ} 37.3^{\prime} \mathrm{N}, 108^{\circ} 51.2^{\prime} \mathrm{W}$ & 30 & 0.0025 & 0.63 \\
& 150 & $<0.001$ & 0.01 \\
& 300 & $<0.001$ & 0.15 \\
Resolute Passage, $74^{\circ} 40^{\prime} \mathrm{N}, 95^{\circ} 15^{\prime} \mathrm{W}$ & 5 & 0.02 & 0.79 \\
& 60 & 0.01 & 0.83 \\
& 120 & 0.009 & 0.80 \\
\hline
\end{tabular}

Table 4. Uptake and turnover of ${ }^{3} \mathrm{H}$ leucine at 2 locations in the Arctic

\begin{tabular}{|lrcr|}
\hline Location & $\begin{array}{r}\text { Depth } \\
(\mathrm{M})\end{array}$ & $\begin{array}{c}\text { pmol } \\
\mathrm{h}^{-1}\end{array}$ & $\begin{array}{c}\text { Turn- } \\
\text { over }(\mathrm{yr})\end{array}$ \\
\hline Arctic Ocean, $79^{\circ} 37.3^{\prime} \mathrm{N}, 108^{\circ} 51.2^{\prime} \mathrm{W}$ & 30 & 0.0026 & 439 \\
& 150 & $\mathrm{ca} 0.0002$ & 5708 \\
300 & $\mathrm{ca} 0.0016$ & 7135 \\
& 5 & 0.30 & 3.8 \\
Resolute Passage, $74^{\circ} 40^{\prime} \mathrm{N}, 95^{\circ} 15^{\prime} \mathrm{W}$ & 60 & 0.04 & 28.5 \\
& 120 & 0.02 & 57.1 \\
\hline
\end{tabular}

only after snow had melted from the surface of the ice pack and leads had opened. Annual primary production in the Arctic Ocean basin has been estimated by both Apollonio and English to be $\leq 1 \mathrm{~g} \mathrm{~m}^{-2}$. In the Fram Strait in June-July, Smith et al. (1987) reported a mean photosynthetic rate of $426 \mathrm{mg} \mathrm{C} \mathrm{m}^{-2} \mathrm{~d}^{-1}$ around ice margins, but concluded that photosynthesis overall was low and variable because of extensive ice cover and strong stratification of the water near ice margins. The very sparse showing of ice algae in the Arctic Ocean pack ice surrounding the Canadian Ice Island at a time when it was fully developed in Resolute Passage further suggests a short season for primary production. We did find measurable chlorophyll fluorescence, with a weak maximum in the pycnocline, but we did not confirm the pigment composition by HPLC. Although we did not have enough material to do electron microscopy for positive identification, there appeared to be an accumulation of Synechococcus at $180 \mathrm{~m}$, the bottom of the pycnocline. Smith et al. (1985) reported finding Synechococcus in the Foxe Basin, in the seasonal ice zone, and Gradinger \& Lenz (1989) report cyanobacteria from the East Greenland Current. The latter suggest that Synechococcus are tracers of warm

Table 5. Uptake and assimilation of ${ }^{14} \mathrm{C}$ glutamic acid at 2 locations in the arctic

\begin{tabular}{|lcrc|}
\hline Location & Depth $(\mathrm{m})$ & pmol h ${ }^{-1} \pm 2 \mathrm{SE}$ & $\%$ Assimilation $\pm 2 \mathrm{SE}$ \\
\hline Arctic Ocean, $79^{\circ} 37.3^{\prime} \mathrm{N}, 108^{\circ} 51.2^{\prime} \mathrm{W}$ & 30 & $26.7 \pm 2.9$ & $13.9 \pm 0.22$ \\
& 150 & $1.3 \pm 0.6$ & $16.4 \pm 6.2$ \\
Resolute Passage, $77^{\circ} 40^{\prime} \mathrm{N}, 95^{\circ} 15^{\prime} \mathrm{W}$ & 300 & $0.8 \pm 0.2$ & $32.1 \pm 4.0$ \\
& 5 & $138.1 \pm 20.0$ & $20.6 \pm 1.6$ \\
Ice algae slurry & 60 & $32.7 \pm 8.4$ & $34.0 \pm 1.4$ \\
\end{tabular}


water masses into the Arctic Basin. We also found fluorescent pigments in the flocculent aggregates at depths of 155 to $300 \mathrm{~m}$. They were more orange in color than the Synechococcus, suggestive of remains of phytoplankton that had passed through the guts of zooplankters. Although there were no organic aggregates in the $30 \mathrm{~m}$ surface water, pigmented or otherwise, the presence of occasional clusters of bacteria is an indication of some active bacterial growth, possibly around some small organic matrices. The undersaturation of oxygen in the Arctic underwater, below the polar surface water, further suggests that there is some longterm fallout and utlization of organic matter at depth Hargrave et al. (1989) report that sedimentation rates below the Canadian Ice Island are the lowest reported for any ocean region. Overall, the evidence suggests exceptionally low rates of photosynthetic activity under the permanent pack ice in June.

We did not measure photosynthesis in Resolute Passage, but Welch \& Kalff (1975) estimated a combined annual production of ice algae and phytoplankton on the order of $80 \mathrm{~g} \mathrm{~m}^{-2}$. A more recent evaluation of production of ice algae in Resolute Passage suggests a somewhat lower annual production (Smith et al. 1988). Secondary productivity of higher organisms appears to be commensurate qualitatively with this difference in primary production between the Arctic Ocean at the Ice Island location and Resolute Passage. However, local concentrations of larger organisms can give deceptive impressions of energy flux. The appearance of secondary production may be enhanced highly seasonal migrations of the larger organisms. However, in June seals were abundant and were catching fish. Bears were reported on the fast ice. Thus, a resident, overwintering population of top predators is present in the Resolute Passage-Barrow Strait region. Amphipods and copepods are relatively abundant (Conover et al. 1986). In qualitative terms, the Resolute area has higher secondary productivity than the Arctic Ocean.

The rates of uptake of ${ }^{3} \mathrm{H}$-thymidine that we observed in the Arctic Ocean are among the lowest that have been reported in the global Ocean. We estimated bacterial secondary production from uptake of tritiated thymidine using the conversion factors of Fuhrman \& Azam (1980) and from the uptake of tritiated leucine, using the conversion factors of Kirchman et al. (1985) Fuhrman \& Azam (1980) reported a range of bacterial production rates in the McMurdo Sound region of the Antarctic of $10^{5}$ to $10^{8}$ cells $l^{-1} \mathrm{~d}^{-1}$. Bailiff et al. (1988) report much higher rates in the Bransfield Strait in summer. The rates in Resolute Passage are higher than those in the Arctic Ocean by 1 order of magnitude. Our estimates are near the lower end of those of Fuhrman \& Azam. The estimates based on leucine uptake differ from those based on thymidine (Table 6). All 3 estimates from Resolute Passage vary by a constant factor (leucine estimate $=0.2$ thymidine estimate). The 2 estimates from the polar underwater are similar but differ from the polar surface water. The difference between the production estimates by uptake of thymidine and leucine suggests unbalanced growth. It is surprising that there was no enhancement of bacterial secondary production $5 \mathrm{~m}$ above the bottom in Resolute Passage, where our fluorometer and microscopy both detected an accumulation of pigment. There was, however, no increase in the standing stocks of dissolved free amino acids in the water close to bottom, all 15 amino acids being $<20 \mathrm{nM}$.

Leucine uptake followed a pattern similar to that of thymidine, with very low to undetectable rates in the Arctic Ocean and rates 1 to 2 orders of magnitude higher in Resolute Passage. Leucine uptake was significantly higher immediately under the ice, but not in the water immediately above the bottom. Both Arctic Ocean and Resolute Passage samples contained detectable amounts of dissolved free leucine, but there may

Table 6 . Estimates of bacterial secondary production based on uptake of tritiated thymidine and leucine, $\mathrm{ngC}^{-1} \mathrm{~d}^{-1}$. Thy. midine estimates are based on the high range of Fuhrman \& Azam (1980), and leucine estimates are based on the conversion factors of Kirchman et al. (1985)

\begin{tabular}{|lrrr|}
\hline Location & Depth $(\mathrm{m})$ & Thymidine & Leucine \\
\hline Arctic Ocean & 30 & 27.40 & 0.19 \\
& 150 & 0.11 & 0.01 \\
& 300 & 2.65 & 0.01 \\
Resolute Passage & 5 & 191.00 & 21.80 \\
& 60 & 102.00 & 2.80 \\
& 120 & 95.00 & 1.54 \\
\hline
\end{tabular}

have been differences in concentrations that were below our level of quantification. There appears to be a latent period preceding uptake of leucine in the $30 \mathrm{~m}$ water of the Arctic Ocean but not in the $5 \mathrm{~m}$ water from Resolute Passage (Fig. 4). It is interesting to compare our estimates of turnover time for leucine (Table 4) with the estimates of Hodson et al. (1981) for McMurdo Sound in the Antarctic. The shortest of our values exceeds the longest from McMurdo Sound. This may reflect seasonal differences; their measurements were made in austral summer, ours in boreal spring. Both our comparison of Arctic Ocean with Resolute Passage and the comparison of the productive and unproductive sides of McMurdo Sound by Hodson et al. suggest a bacterial response in both growth and heterotrophic uptake to the availability of labile dissolved substrates. However, Hodson et al. did not measure substrate concentration, and we measured only free amino acids, 


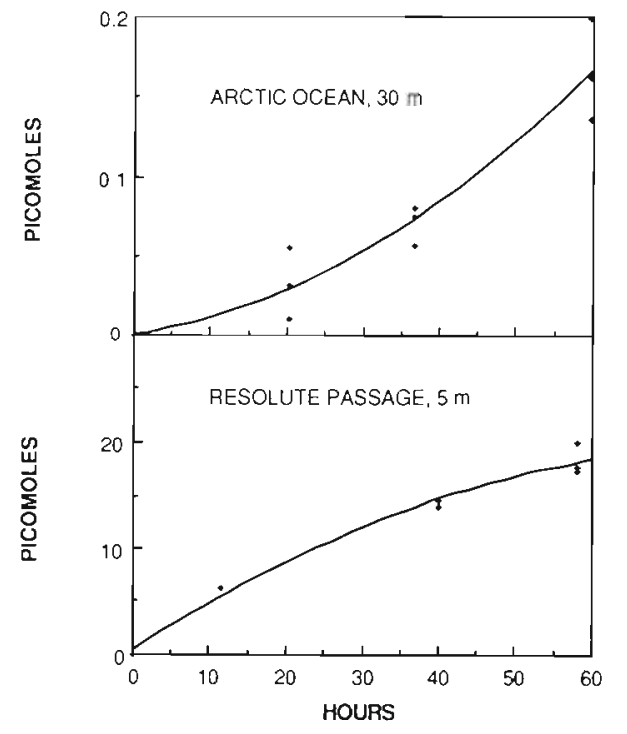

Fig. 4. Time course studies of uptake of ${ }^{3} \mathrm{H}$-leucine in water from the Arctic Ocean and Resolute Passage. Note the different scales

which were mostly below our limit of quantitative detection. Other kinds of dissolved or even particulate substrates may have influenced the observed bacterial response. Moreover, it is not clear if the response to changes in substrate concentration is a linear function over the range from picomolar to micromolar.

Because of the lower specific activity of the ${ }^{14} \mathrm{C}$ glutamic acid, as compared with the ${ }^{3} \mathrm{H}$-leucine, we were increasing the glutamic acid concentration significantly and therefore we were really performing an enrichment experiment, as have others who have used ${ }^{14} \mathrm{C}$-glutamic acid in this way (Morita et al. 1977). The result may be a higher rate of uptake than occurs at the vanishingly low glutamic acid concentrations that were present, both in the Arctic Ocean and Resolute Passage. In the Arctic Ocean there is a clear difference in the response of bacteria in the polar surface water, compared with the lower layers that are isolated by stratification. Resolute Passage also shows a vertical gradient of uptake of glutamic acid, but here it is likely related to the presence of some substrates released from the ice-algae community, although we do not know if significant differences in concentration existed. One reason for choosing the ${ }^{14} \mathrm{C}$ label, in spite of its lower specific activity, was to evaluate assimilation efficiency by recovering the respired $\mathrm{CO}_{2}$. The assimilation showed no clear pattern, but all of our observations of assimilation efficiency were lower than those reported for circum-Antarctic waters by Gillespie et al. (1976) who found a quite uniform $50 \%$ assimilation. There is a need in future to examine the response to a range of substrate concentrations.
We did examine one much higher concentration of dissolved amino acids occurring naturally in the lead water. The glutamic acid concentration in the water from a lead which contained floating clumps of ice algae was $8 \mu \mathrm{M}$, and melted ice collected from the edge of the lead contained $34 \mu \mathrm{M}$ glutamic acid (Table 2). This increase of at least 3 orders of magnitude in glutamic acid concentration produced an increase in uptake of 1 order of magnitude, relative to $5 \mathrm{~m}$ water. Moreover, this measurement was a true tracer experiment, because we increased the glutamic acid concentration by $0.4 \%$. When specific activity was corrected, using analytical HPLC values for glutamic acid and assuming linear interpolation, uptake was highly linear with time. This underscores the value of having analytical data on dissolved amino acids when performing tracer experiments with natural microbial communities.

The ice algae community within sea ice has been shown to contain an active bacterial component (Grossi et al. 1984, Sullivan \& Palmisano 1984, Horner 1985, Kottmeier et al. 1987. Smith et al. 1989), although Smith et al point out that only a small fraction of ice algal production is utilized in situ by the heterotrophic ice community. Our lead water sample appears to be an extension of this heterotrophic activity into the water, with concentrations of free amino acids lower than in the ice but still orders of magnitude above ambient concentrations in the remainder of the water column. Where the ambient amino acid concentrations dropped below micromolar, however, there was no response of heterotrophic bacteria to the presence of ice algae. We find it particularly noteworthy that the water near the bottom contained a readily detectable concentration of fallen ice algae, but neither a detectable elevation of dissolved free amino acids nor an increase in heterotrophic activity or productivity of bacteria was observed. Since there was no significant difference in temperature between the 2 sites, both being $-1.7^{\circ} \mathrm{C}$, such differences as we found must have resulted from existing or recent differences in substrate availability, although as Smith et al. (1989) state, this does not eliminate the possibility of a temperature effect on substrate utilization. Button \& Robertson (1988) found bacterial uptake of amino acids in Alaskan waters to be proportional to the concentration of dissolved free amino acids. In the Canadian sector of the Arctic Ocean, bacterial populations survive at refuge population densities of $10^{4}$ to $10^{-5} \mathrm{ml}^{-1}$. Their uptake rates of leucine per cell were $5 \times 10^{-6} \mathrm{fmol} \mathrm{cell}^{-1} \mathrm{~h}^{-1}$ at $300 \mathrm{~m}$ and $2 \times 10^{-5}$ in the upper water. In Resolute Passage, bacterial numbers were $10^{5} \mathrm{ml}^{-1}$. Leucine uptake was $2.4 \times 10^{-3} \mathrm{fmol}_{\text {cell }}^{-1} \mathrm{~h}^{-1}$ at $60 \mathrm{~m}$ and $1.4 \times 10^{-4}$ both near bottom and just beneath the ice. Since the concentration of dissolved leucine was below our detection 
limit at all depths, we do not know if these differences reflect differences in dissolved leucine although it seems unlikely that the concentration is highest at mid depth. Previous reports from polar waters suggest low rates of heterotrophic activity and bacterial production in oceanic waters of low productivity (Hanson et al 1983) and high rates in straits and sounds and near melting ice margins. Harrison et al. (1987) found summer bacteria populations to be $5 \times 10^{5} \mathrm{ml}^{-1}$ in Jones Sound and $10^{6} \mathrm{ml}^{-1}$ in Baffin Bay, with turnover times of dissolved amino acids of ca 3 to $10 \mathrm{~d}$. Bölter \& Dawson (1982) found micromolar amounts of dissolved free amino acids and active heterotrophic uptake of these during summer bloom conditions at stations in the South Shetland Islands. Although summer water temperature is around $0^{\circ} \mathrm{C}$ in the South Shetland Islands, there is a summer pulse of heterotrophic activity associated with the summer phytoplankton bloom. Haberstroh et al. (1987) found on the order of 10 to $100 \mathrm{n.M}$ glutamic acid in Bransfield Strait waters in February and reported rapid turnover. Similar heterotrophic responses are seen in the Canadian archipelago in summer (Harrison et al. 1987). We did not find a comparable response to ice algae in June, except in the immediate ice-algae community itself. We found high concentrations of free amino acids only in sea ice and in meltwater stratified at the surface of a lead, although quantities of ice algae were being released to the water in Resolute Passage and accumulating near the bottom Although our results show that bacteria are more active in the ice algae community than in bulk seawater, excess amino acids had accumulated at a time when the algal bloom had peaked and was melting out of the ice. Bacterial production appeared not to be keeping pace with substrate production. Moreover, the fallout of algae was accumulating in the water near bottom but was not being utilized rapidly by bacteria. This may prolong the residence time of the released ice algae in the water, enhancing the opportunities for both pelagic and benthic macroconsumers to utilize them

Various scenarios have been reported for the production of ice algae and their release to the food web of the bulk water. In the Antartic, the most intense ice algae production occurs at the ice edge, as snow melts from the surface and the ice thins, increasing insolation (Sullivan et al. 1988). In Resolute Passage and probably in most of the Canadian archipelago, snow cover is scant, averaging about $10 \mathrm{~cm}$, and ice algae production occurs under the fast ice in April and May, before melt begins (Welch \& Bergmann 1989). Also, because of the thin snow cover, insolation reaching the brown icealgae layer heats it and causes the ice to thin at the bottom in May and June, releasing ice algae early in the melt, well before ice breakup, and causing a distinctly bimodal primary production curve, with spring and summer peaks. This temporal distribution of primary production, and the limited microbial response to the bloom of ice algae, may have a favorable effect on secondary production in the Canadian archipelago. These observations, as well as those of Smith et al (1989) and Pomeroy \& Deibel (1986), and earlier experimental work by Goodrich \& Morita (1977) and Christian \& Wiebe (1974) suggest that bacterial assimilation of substrates in cold water may be limited by an interaction of temperature and substrate concentration. Haight \& Morita (1966) found that membrane permeation and glycolytic enzyme level of Vibrio marinus MP-1 were impaired when cultured at $4{ }^{\circ} \mathrm{C}$ with unamended seawater as the growth medium. In our observations of natural microbial communities, only where we find substrate concentrations that are orders of magnitude above those in bulk seawater, such as in the ice algae community and small leads in melting sea ice, do we find active bacterial growth and substrate utilization. However, we need better tests of that hypothesis and elucidation of a biochemical mechanism.

Acknowledgements. This work was supported by NSERC grant A2644, with logistical support by the Polar Continental Shelf Project. Transportation for J. Dunphy was funded by the Labrador Institute of Northern Studies. Sample processing at the University of Georgia was supported by the U.S. National Science Foundation. We thank Robert Conover for generously sharing both the facilities in the Bayfield Laboratory at Resolute, NWT and his research hut on the ice in Resolute Passage and for much useful advice. We thank Les Harris and Barry Hough for their help with logistics. W. J. Wiebe and 2 anonymous reviewers made helpful comments on an earlier draft of this report.

\section{LITERATURE CITED}

Anderson, A. J., Marquart, G., Scherneck, H.-G. (1988). Arctic geodynamics: a satellite altimeter experiment for the European Space Agency Earth Remote-Sensing Satellite. EOS 69: $873-881$

Anderson, L. G., Jones, E. P., Kolterman, K. P., Schlosser, P. (1989). The first oceanographic section across the Nansen Basin to the Arctic Ocean. Deep Sea Res. 36: 475-482

Apollonio, S. (1959). Hydrobiological measurements on IGY Drifting Station Bravo. Trans. Am. geophys. Un. 40: 316-319

Bailiff, M. D., Jones, D, Nawrocki, M., Tilbrook, B., Haberstroh, B., Tien, G., Taylor, G. T., Karl, D. M. (1988) RACER: bacterial abundance and thymidine incorporation in the Bransfield Strait, 1986-1987. Antarctic J. U.S. 22 (5): 150-153

Bölter, M., Dawson, R. (1982). Heterotrophic utilisation of biochemical compounds in antarctic waters. Neth. J. Sea Res. 16: 315-332

Button, D. K., Robertson, B. R. (1988). Distnbution, specific affinities, and partial growth rates of aquatic bacteria by high resolution flow cytometry. Eos 69: 1106

Chrzanowski, T. H. (1988). Consequences of accounting for isotopic dilution in thymidine incorporation assays. Appl. environ. Microbiol. 54: 1868-1870 
Christian, R. R., Wiebe, W. J. (1974). The effects of temperature upon the reproduction and respiration of a marine obligate psychrophile. Can. J. Microbiol. 20: 1341-1345

Conover, R. J., Herman, A. W., Prinsenberg, S. J. (1986). Distribution of and feeding by the copepod, Pseudocalanus, under fast ice during the arctic spring. Science 232: $1245-1247$

Cota, G. F., Prinsenberg, S. J., Bennett, E. B., Loder, J. W., Lewis, M. R., Anning, J. L., Watson, N. H. F., Harris, L. R. (1987). Nutrient fluxes during extended blooms of arctic ice algae. J. geophys. Res. 92C2: 1951-1962

Douglas, D. J., Novitsky, J. A., Fournier, R. O. (1987). Microautoradiography-based enumeration of bacteria with estimates of thymidine-specific growth and production rates. Mar. Ecol. Prog. Ser. 36: 91-99

English, T S. (1959). Primary production in the Central North Polar Sea; Drifting Station Alpha, 1957-1958. In: Sears, M. (ed.) Int. Oceanogr Congr. Preprints. AAAS, Washington, p. $838-839$

English, T. S. (1961). Some biological oceanographic observations in the central North Polar Sea. Drift Station Alpha. 1957-1958. Arct. Inst. N. Am. Res. Pap. 13: viii-80

Fuhrman, J. A., Azam, F. (1980). Bacterioplankton secondary production estimates for coastal waters of British Columbia, Antarctica, and California. Appl. environ. Microbiol 39: $1085-1095$

Gillespie, P. A., Morita, R. Y., Jones, L. P. (1976). The heterotrophic activity for amino acids, glucose and acetate in antarctic waters. J. oceanogr. Soc. Japan 32: 74-82

Goodrich, T D., Morita, R. Y (1977). Low temperature inhibition on binding, transport and incorporation of leucine, arginine, methionine, and histidine in Escherichia coli. $\mathrm{Z}$ Allg. Mikrobiol. 17: 91-97

Gradinger, R., Lenz, J. (1989). Picocyanobacteria in the high arctic. Mar. Ecol. Prog. Ser. 52: 99-101

Grossi, S. M., Kottmeier, S. T., Sullivan, C. W. (1984). Sea ice microbial communities. 3. Seasonal abundance of microalgae and associated bacteria, McMurdo Sound, Antarctica Microb. Ecol. 10: 231-242

Haberstroh, P. R., Bailiff, M. D., Tien, G., Taylor, G. T., Jones, D., Tilbrook, B., Newrocki, M., Karl, D. M. (1988). RACER: dissolved free amino acid concentrations, molecular composition, and microbial uptake rates in the Bransfield Strait. Antarctic J. U.S. 22: 153-156

Haight, J. J., Morita, R. Y. (1966). Some physiological differences in Vibrio marinus grown at environmental and optimal temperatures. Limnol. Oceanogr 11:470-474

Hanson, R. B., Lowery, K. H., Shafer, D., Pope, D. H. (1983) Microbes in antarctic waters of the Drake Passage: vertical patterns of substrate uptake, productivity and biomass in January 1980. Polar Biol. 2: 179-188

Hargrave, B. T., Bodungen, B. v., Conover, R. S., Phillips, S. G., Vass, W. P. (1989). Seasonal changes in sedimentation of particulate matter and lipid content of zooplankton collected by sediment trap in the Arctic Ocean off Axel Heiberg Island. Polar Biol. 9: 467-475

Harrison, W. G., Li, W. K. W., Smith, J. C., Head, E. J. H. Longhurst, A. R. (1987). Depth profiles of plankton, particulate organic matter and microbial activity in the eastem Canadian arctic during summer. Polar Biol. 7: 207-224

Hilber, W. D. (1980). Sea ice growth, drift and decay. In: Colbeck, S.C. (ed.) Dynamics of snow and ice masses. Academic Press, New York, p. 141-209

Hobbie, J. E., Crawford, C. C. (1969). Respiration corrections for bacterial uptake of dissolved organic compounds in natural waters. Limnol. Oceanogr. 14: 528-532

Hodson, R. E. F., Azam, A., Carlucci, F., Fuhrman, J., Karl,
D. M., Holm-Hansen, O. (1981). Microbial uptake of dissolved organic matter in McMurdo Sound, Antarctica. Mar. Biol. 61: 89-94

Horner, R. A. (1985). Ecology of sea ice microalgae. In: Horner, R. A. (ed.) Sea ice biota. CRC Press, Boca Raton, p. 83-103

Kirchman, D., Hodson, R. (1984). Inhibition by peptides of amino acid uptake by bacterial populations in natural waters: implications for the regulation of amino acid transport and incorporation. Appl. environ. Microbiol. 47 $624-631$

Kirchman, D., K'nees, E., Hodson, R. (1985). Leucine incorporation and its potential as a measure of protein synthesis by bacteria in natural aquatic systems. Appl. environ. Microbiol. 49: 599-607

Kottmeier, S. T., Grossi, S. M., Sullivan, C. W. (1987). Sea ice microbial communities. VIII. Bacterial production in annual sea ice of McMurdo Sound, Antarctica. Mar. Ecol. Prog. Ser. 35: 175-176

Lee, S., Fuhrman, J. A. (1987). Relationships between biovolume and biomass of naturally derived marine bacterioplankton. Appl. environ. Microbiol. 53: 1298-1303

Maykut, G. A. (1985). The ice environment. In: Horner, R. A (ed.) Sea ice biota. CRC Press, Boca Raton, p. 21-82

Morita, R. Y., Griffiths, R. P., Hayasaka, S. S. (1977). Heterotrophic activity of microorganisms in antarctic waters. In Llano, G. A. (ed.) Adaptations within Antarctic ecosystems. Smithsonian Inst., Washington, D.C., p. 99-113

Nansen, F. (1902). The biological conditions of the north polar basin. The Norwegian North Polar Expedition 1893-1896. 3: $422-427$

Nishino, S. F. (1986). Direct acridine orange counting of bacteria preserved with acidified Lugol iodine. Appl. environ. Microbiol. 52: 602-604

Pomeroy, L. R., Deibel, D. (1986). Temperature regulation of bacterial activity during the spring bloom in Newfoundland coastal waters. Science 233: 359-361

Pomroy, A. J. (1984). Direct counting of bacteria preserved with Lugol iodine solution. Appl. environ. Microbiol. 47: $1191-1192$

Robarts, R. D.. Wicks, R. J. (1989). [Methyl- ${ }^{3} \mathrm{H}$ ] thymidine macromolecular incorporation and lipid labelling: their significance to DNA labelling during aquatic bacterial growth rate measurements. Limnol. Oceanogr. 34: 213-222

Silfer, J. A., Engel, M. H., Macko, S. A. (1990). The effect of hydrothermal processes on the distribution and stereochemistry of amino acids in recent antarctic sediments. Appl. Geochem. 5: (in press)

Smith, J. C., Platt, T., Li, W. K. W., Horne, P. W., Harrison, W. G., Subba Rao, D. V., Irwin, D. B. (1985). Arctic marine photoautotrophic picoplankton. Mar. Ecol. Prog. Ser. 20: 207-220

Smith, R. E. H., Anning, J., Clement, P., Cota, G. F. (1988) Abundance and production of ice algae in Resolute Passage, Canadian Arctic. Mar. Ecol. Prog. Ser. 48: 251-263

Smith, R. E. H., Clement, P., Cota, G. F. (1989). Population dynamics of bacteria in arctic sea ice. Microb. Ecol. 17 $63-76$

Smith, W. O. Jr, Baumann, M. E. M., Wilson, D. L., Aletsee, L. (1987). Phytoplankton biomass and productivity in the marginal ice zone of the Fram Strait during summer 1984 J. geophys. Res. 92 (C7): 6777-6786

Subba Rao, D. V., Platt, T. (1984). Primary production of Arctic waters. Polar Biol. 3: 191-201

Sullivan, C. W., McClain, C. R., Comiso, J. C., Smith, W. O. Jr 1988). Phytoplankton standing crops within an antarctic ice edge assessed by satellite remote sensing. I. geophys. Res. 93 (C10) 12: $487-498$ 
Sullivan, C. W., Palmisano, A. C. (1984). Sea ice microbial communities: distribution abundance and diversity of ice bacteria in McMurdo Sound, Antarctica. Appl. environ. Microbiol. 47: 788-795

Weiss, R. F. (1970). The solubility of nitrogen, oxygen and argon in water and seawater. Deep Sea Res. 17: 721-735

Welch, H. E., Bergmann, M. A. (1989). Seasonal development of ice algae and its prediction from environmental factors

This article was presented by Drs B. and E. Sherr, Sapelo Island, Georgia, USA near Resolute, N. W I., Canada. Can. J. Fish. Aquat. Sci. 46: 1793-1804

Welch, H. E., Kalff, J. (1975). Marine metabolism at Resolute Bay, Northwest Territories. In: Proc. Circumpolar Conference Northern Ecology, II. NRC Canada, Ottawa, p. 67-75

Wicks, R. J., Robarts, R. D. (1987). The extraction and purification of DNA labelled with [methyl- ${ }^{3} \mathrm{H}$ - thymidine in aquatic bacterial production studies. J. Plankton Res. 9: 1159-1166

Manuscript first received: September 28, 1989 Revised version accepted: November 30, 1989 